\title{
More Bang for the Buck: Investing in Early Childhood Development
}

Spending resources on early childhood may be one of the best investments a government can make. To begin with, the earlier the government invests in a child, the longer the country has to reap the benefits. Moreover, the rate of return to some investments may be lower if made later in life (e.g., it may be hard to achieve gains in IQ after a certain age). Finally, investments in early childhood development generate potential ripple effects on investments made later on; in other words, the returns to investment in human capital are higher if investments were made in the early years. Also, disparities in child development outcomes are present before children enter primary school. Public investment in early childhood can be a powerful equalizing force. Do government spending priorities reflect these opportunities? How can governments in Latin American and Caribbean countries maximize the returns to investments in early childhood development?

\section{Under 5 and Underserved: Government Spending on Early Childhood Development}

While more spending does not always go hand-in-hand with better outcomes, public budgets reveal government priorities. Historically, investing in children has been an important goal for governments in the region, but until recently, the focus has not been on early childhood (age $0-5$ years). ${ }^{1}$ 
Public spending on children (age 0-12 years) increases with age (Table 6.1). Countries in the region spend only 0.4 percent of GDP on average on early childhood (age $0-5$ years), compared to 1.6 percent of GDP on average on middle childhood (age 6-12 years). In some countries, only 10 percent of the budget for children is allocated to early childhood (ages $0-5$ ). Spending on early childhood services and programs in the region makes up less than 6 percent of total social spending (i.e., spending on education, health, housing, and social protection).

On average, governments in Latin America and the Caribbean spend about $\$ 300$ per child per year on early childhood, in contrast to $\$ 1,000$ on middle childhood, but these sums vary widely. The governments of higher-income countries in the region tend to spend more on early childhood than their lower-income counterparts. Yet patterns also vary among countries with similar income levels. Among the richer countries, for example, public spending per child on early childhood ranges from $\$ 253$ in Peru to $\$ 882$ in Chile.

Table 6.1 Public Expenditure on Children by Age Group, Early and Middle Childhood

\begin{tabular}{|c|c|c|c|c|c|}
\hline \multirow[t]{2}{*}{ Country } & \multirow[t]{2}{*}{$\begin{array}{c}\text { GDP } \\
\text { in \$ per capita }\end{array}$} & \multicolumn{2}{|c|}{$\begin{array}{l}\text { Expenditure } \\
\text { in \$ per child }\end{array}$} & \multicolumn{2}{|c|}{$\begin{array}{c}\text { Expenditure } \\
\text { as percent of GDP }\end{array}$} \\
\hline & & $\begin{array}{c}\text { Ages } \\
0-5\end{array}$ & $\begin{array}{l}\text { Ages } \\
6-12\end{array}$ & $\begin{array}{c}\text { Ages } \\
0-5\end{array}$ & $\begin{array}{l}\text { Ages } \\
6-12\end{array}$ \\
\hline Chile & 15,732 & 882 & 2,608 & 0.5 & 1.7 \\
\hline Brazil & 11,208 & 641 & 2,179 & 0.5 & 2.3 \\
\hline Mexico & 10,307 & 488 & 1,041 & 0.6 & 1.4 \\
\hline Colombia & 7,826 & 402 & 844 & 0.6 & 1.6 \\
\hline Peru & 6,660 & 253 & 464 & 0.4 & 0.9 \\
\hline Dominican Republic & 5,826 & 58 & 451 & 0.1 & 1.1 \\
\hline Jamaica & 5,290 & 127 & 848 & 0.3 & 2.1 \\
\hline Guatemala & 3,478 & 83 & 305 & 0.4 & 1.7 \\
\hline Nicaragua & 1,851 & 21 & 226 & 0.2 & 2.0 \\
\hline Average & 7,575 & 328 & 996 & 0.4 & 1.6 \\
\hline
\end{tabular}

Notes: Data on expenditure and GDP are in current dollars for 2012 except for Colombia, which are for 2011.

Source: Author's elaboration based on Alcázar and Sánchez (2014), World Development Indicators, and ECLAC. 


\section{Box 6.1 Gaps in Budget Data}

Calculating government expenditures on children on a cross-country basis is a complicated task involving methodological decisions and data limitations. Following Alcázar and Sánchez (2014), this chapter used a three-step procedure to estimate public expenditures in nine Latin American and Caribbean countries between 2004 and 2012. First, public social spending on children from age 0 to 12 years was defined as a composite estimate of expenditures on education (preschool and primary) and social programs, including daycare, parenting programs, conditional cash transfers, and in-kind benefits. Second, expenditure data from budget reports and directly from budget offices and the relevant sectoral ministries were used. Third, the Government Finance Statistics Manual 2001 served as a guide to select budget classifications and construct estimates of public social spending on children.

The data collection exercise faced several limitations:

- Public access to budget information. Peru is the only country of the nine reviewed here that has online access to an integrated financial management system providing disaggregated information that allows for identifying social expenditures benefiting children.

- Expenditures at the subnational level. The availability of budget information on social expenditures at subnational levels is limited in some countries, particularly in Mexico.

- Health expenditures. Health expenditures are not included in the estimates of public social spending on children due to weaknesses in the quality and availability of budget information on the health sector in most selected countries, except for Chile and Peru.

Tracking the overall level of public expenditures on children is an important task for governments that are concerned about the wellbeing of children. Peru has made significant progress in the use of public management instruments that facilitate the monitoring of budget execution on children. In 2008, Peru gradually implemented performance-based budgeting (PBB), starting with five pilot strategic programs and involving all levels of government. By 2014, 41 percent of the overall budget was formulated under PBB. Additionally, Peru's integrated financial management system and performance monitoring system of PBB programs, called Resulta, promotes budget transparency and accountability.

Source: Alcázar and Sánchez (2014). 
Public spending in Jamaica is twice as high or even more than its regional peers with similar per capita incomes. While income is certainly important, it is not the only driver in the allocation of public spending. For example, Guatemala boasts the largest allocation to early childhood development relative to its overall social spending envelope. Thus, there is room for changing policy priorities and shifting more resources to early childhood.

Public spending on early childhood is not only low relative to investments in middle childhood, but also with respect to spending on all other age ranges, particularly the elderly who receive pensions and other transfers against risks linked to old age. For instance, even though Chile, Guatemala, and Peru have very different population profiles, they share similar patterns in terms of the distribution of spending over the life cycle. These countries all spend between seven and nine times as much on the elderly as on children aged $0-5$, measured on a per capita basis (Figure 6.1). ${ }^{2}$

The composition of public spending on early childhood also varies in the region (see Table 6.2). Expenditure on early childhood development comprises preschool and various social programs. The top three social programs that reach children during the early years are preschool, daycare, and conditional cash transfer (CCT) programs. In general, preschool spending is highest, at almost 0.2 percent of

\section{Figure 6.1 Per Capita Public Spending by Age Group and} Age Composition

a. Chile

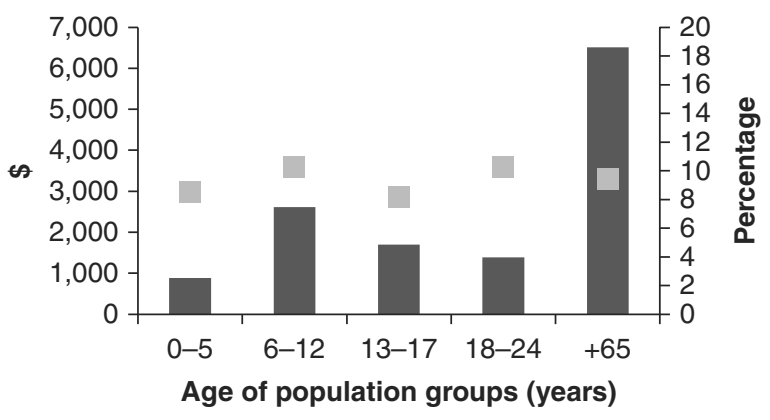

Spending per capita (\$) Share of the population (\%) 


\section{b. Guatemala}

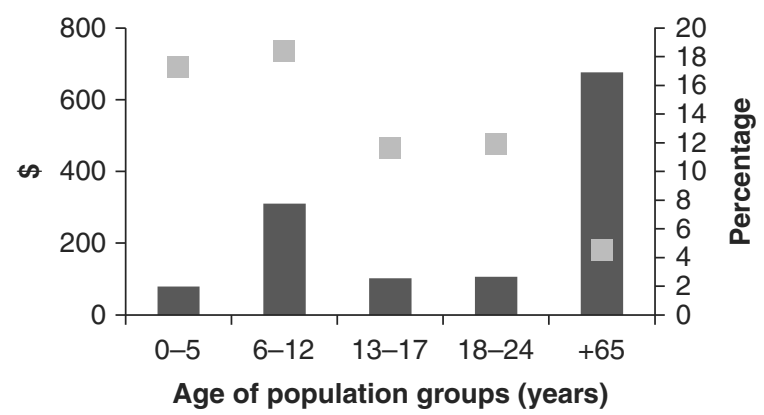

Spending per capita (\$) $\square$ Share of the population (\%)

c. Peru

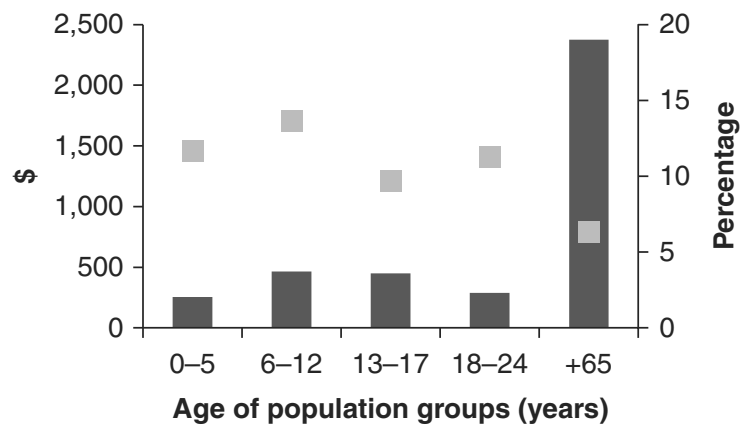

Spending per capita (\$) - Share of the population (\%)

Source: Authors' calculations based on Alcázar and Sánchez (2014) and ECLAC.

GDP in the region, while daycare spending amounts to less than 0.1 percent of GDP. Parenting programs receive the smallest allocation of the overall budgets. ${ }^{3}$

Some countries spend more on preschool than daycare, including Guatemala, Mexico, and Peru. Other countries allocate more public resources to daycare than preschool, such as Chile and Colombia. Public daycare programs are not offered in Jamaica, but there is almost universal coverage of preschool education. Conditional cash transfers and school feeding programs for early childhood are offered in all countries included in the table (except for CCT, in Nicaragua). Budgets for both programs vary across countries, but levels are below 0.1 percent of GDP. 
Table 6.2 Public Expenditure on Early Childhood by Program (\% of GDP)

\begin{tabular}{lccccc}
\hline & $\begin{array}{c}\text { Parenting } \\
(\mathbf{0}-\mathbf{5} \\
\text { years })\end{array}$ & $\begin{array}{c}\text { Daycare } \\
\mathbf{( 0 - 5} \\
\text { years })\end{array}$ & $\begin{array}{c}\text { Preschool } \\
\mathbf{( 3 - 5} \\
\text { years })\end{array}$ & $\begin{array}{c}\text { School } \\
\text { feeding } \\
(\mathbf{4 - 5} \text { years })\end{array}$ & $\begin{array}{c}\text { CCT } \\
\mathbf{( 0 - 5} \\
\text { years) }\end{array}$ \\
\hline Chile & 0.00 & 0.25 & 0.10 & 0.06 & 0.05 \\
Colombia & 0.06 & 0.19 & 0.20 & 0.03 & 0.07 \\
Dominican Republic & n.d. & 0.03 & 0.02 & 0.01 & 0.05 \\
Guatemala & 0.00 & 0.02 & 0.29 & 0.02 & 0.09 \\
Jamaica & n.d. & n.d. & 0.21 & 0.03 & 0.01 \\
Mexico & 0.00 & 0.02 & 0.40 & n.a. & 0.06 \\
Nicaragua & 0.03 & 0.06 & 0.03 & 0.04 & n.d. \\
Peru & 0.02 & 0.02 & 0.26 & 0.06 & 0.05 \\
Average & 0.02 & 0.08 & 0.19 & 0.04 & 0.05 \\
\hline
\end{tabular}

Notes: n.d. $=$ no data; n.a. $=$ not applicable. Data are for 2012, except for Colombia, which are for 2011. The ages for the target children's groups are presented within parentheses in column titles.

Source: Author's elaboration based on Alcázar and Sánchez (2014).

Finally, it is important to place Latin American and Caribbean regional early childhood public expenditure in a broader comparative perspective. The Organisation for Economic Co-operation and Development (OECD) presents several early childhood development indicators in its Family Database. Based on two specific components of spending - the share of pre-primary and daycare spending in GDP-Latin America and the Caribbean spends less than half the OECD average ( 0.7 percent). In contrast to Nordic countries, where early childhood investments exceed 1 percent of GDP and daycare services account for more than half the total, the share of daycare spending in general is much lower in the region, although exceptions like Chile, Colombia, and Nicaragua stand out (Figure 6.2).

\section{Public Spending Trends: On the Way Up}

Even though early childhood public spending remains low in relative terms, investments have increased significantly over the past decade across the region. For example, Chile, the Dominican Republic, and Guatemala spent between two and four times as much in 2012 as at the beginning of the 2000s on a per child basis. Preschool spending and conditional cash transfer programs have expanded in most countries, accompanied to a lesser extent by daycare and parenting programs. 


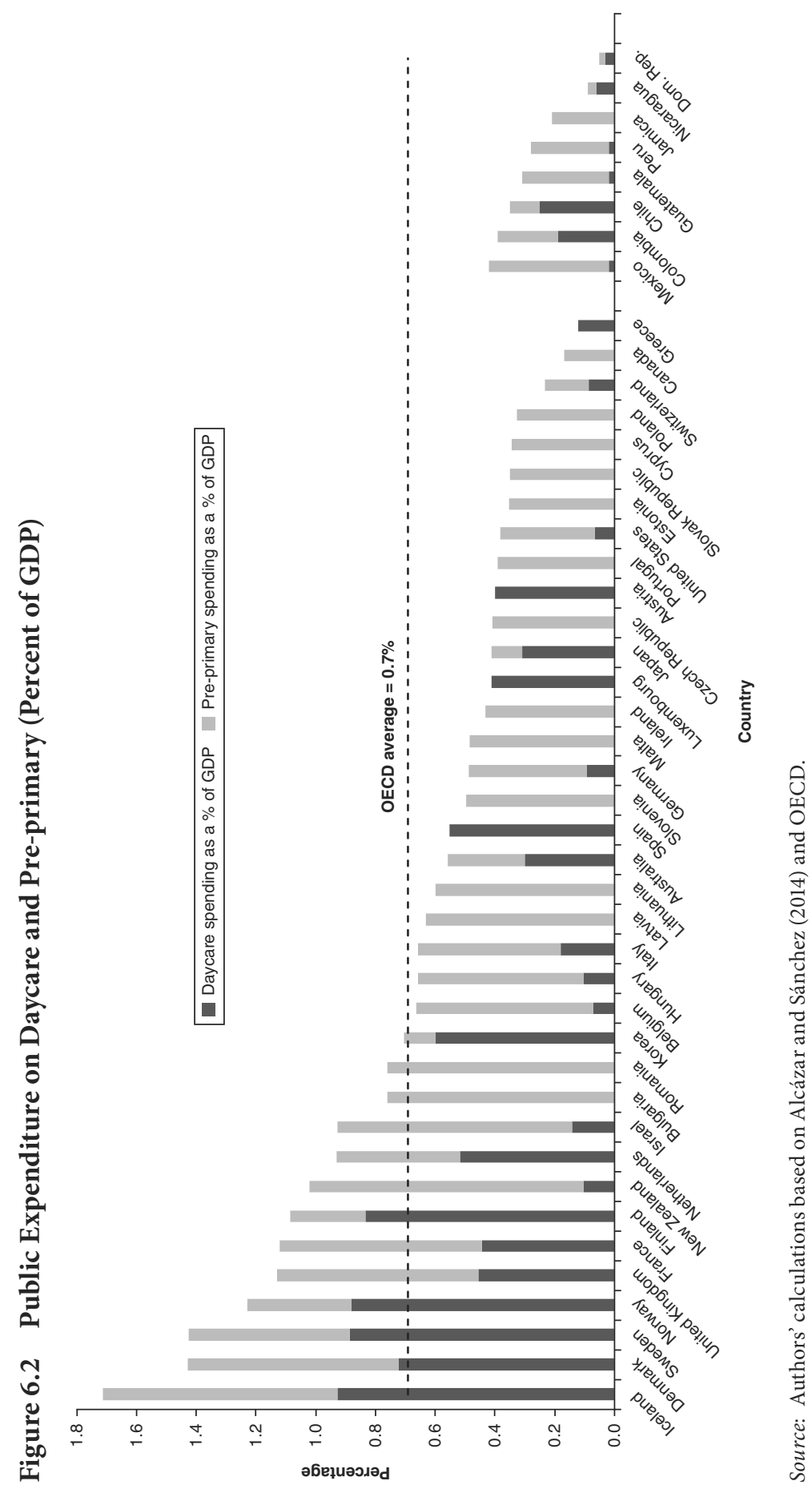


Figure 6.3 Per Child Early Childhood Spending, 2004-12 (Annual Percentage Growth)

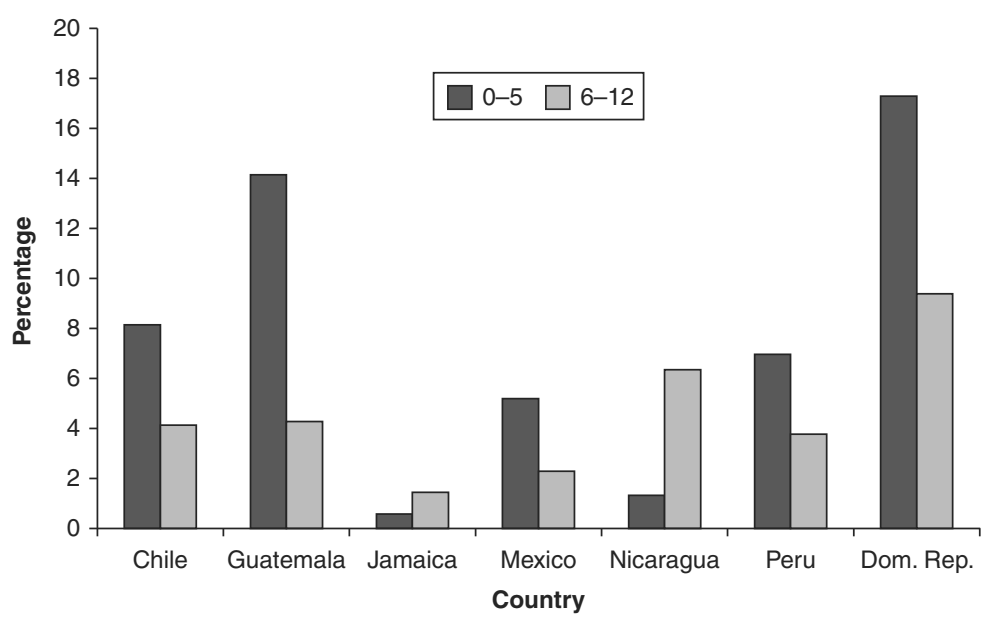

Source: Authors' calculations based on Alcázar and Sánchez (2014) and ECLAC.

On a regional basis, total early childhood public spending per capita grew at an annual rate of 7 percent per year in real terms between 2004 and 2012 (Figure 6.3). In particular, expenditures expanded during the 2008-09 crisis, and in general grew at faster rates than overall social spending. The case of Nicaragua is illustrative: early childhood spending grew 5 percent during 2009 while the economy contracted 2 percent. After the crisis, the growth rate of expenditures slowed in response to tighter fiscal conditions in most countries. These dynamics raise the question of whether small children will continue to benefit as much from public budget allocations as they did in the past decade. They also put the spotlight on efficiency issues: if room for increasing public expenditure levels is severely constrained, spending well becomes a policy priority.

\section{Program Costs}

Program costs are critical because they determine the extent to which coverage of public programs can be expanded as governments in the region increase their budgets on early childhood development. 
Program costs are also important to determine the overall resource costs that, together with benefits, determine which types of programs are expected to have the greatest return to investment.

Following the areas analyzed in the book, three major programs are considered. The first is home visits. In this program, trained staff visit mothers of young children in their homes to demonstrate enriching activities through play sessions that include homemade toys, songs, and games. The second program is full-time daycare, which presumably provides children with safe and healthy environments and parents with the freedom to pursue other productive activities. Finally, children attending preschools participate in part-time educational activities to enhance their development and improve school readiness. Table 6.3 summarizes the goals and services of these three types of programs.

The analysis considers two main questions. First, what are the costs related to improving program quality? Second, what are the costs associated with providing home visits daycare and preschool services at different levels of quality? Answering these questions can inform policy decisions on how to improve the quality of existing programs and the options to improve program quality when expanding access to services. To explore the robustness of the results across different Latin American and Caribbean contexts, program costs are derived for three very different countries: Chile, Colombia, and Guatemala.

To simulate costs for different programs, levels of quality, and countries, a model was developed that approximates the annual per child costs for each initiative based on quality parameters (such as educational attainment of caregivers, and the ratio of children to provider) and local wages and prices. Critical parameter values

Table 6.3 Major Early Childhood Programs

\begin{tabular}{llll}
\hline & Home visits & Daycare & Preschool \\
\hline Goal & $\begin{array}{l}\text { Improve parenting } \\
\text { practices }\end{array}$ & $\begin{array}{l}\text { Child care and } \\
\text { development }\end{array}$ & Child development \\
Services provided & $\begin{array}{l}\text { Demonstrations } \\
\text { at the homes with } \\
\text { parent and child }\end{array}$ & $\begin{array}{l}\text { Full-time child } \\
\text { care }\end{array}$ & $\begin{array}{l}\text { Part-time educational } \\
\text { activities }\end{array}$ \\
\hline
\end{tabular}

Source: Author's elaboration. 
were defined to approximate costs to those of prototype basic- and enhanced-quality programs that already exist in the region.

The model incorporates two distinct dimensions of program quality that were discussed in Chapters 4 and 5. First, structural quality refers to the type of resources that tend to remain stable across time, such as physical facilities, average schooling attainment of caregivers, and the ratio of children per adult. Second, process quality refers to the frequency and nature of interactions between caregivers and children, among children, and between caregivers and families, all of which in principle can be changed relatively quickly.

The model estimates costs for three groups of inputs: human resources; infrastructure; and nutrition, equipment, and materials. Investments in these inputs can be expected to directly improve measures of structural quality. This upgrading process may entail decreasing child-adult ratios, raising the required educational attainment of teachers, increasing the size of physical infrastructure, and improving the nutritional services provided. Chapter 4 , for example, described the case of a quality-upgrading experience in Colombia where some children who were previously attending home-based daycare (largely in the homes of community mothers) were transferred to formal daycare centers. In this instance, large investments in structural inputs, such as buildings and sanitation, were made (Bernal and others 2014b).

The model also estimates costs for a fourth input: expenses in specific training and supervision. Investments in this category of inputs focus directly on improving process quality measures by promoting better interaction between caregivers and children. An example of this type of initiative is a program that provided three-day training and a structured curriculum to community health workers in Pakistan to develop stimulating activities for parents of young children to use at their homes (Yousafzai and others 2014). Coaching programs that involve an initial training followed by observation sessions and feedback to caregivers can be effective in improving childprovider interactions. A review of the US literature documented that in 14 out of 16 evaluations, coaching programs generated improvements in the quality of teacher-child interactions (Aikens and Akers 2011). Box 6.2 presents the values assumed for key structural and process quality parameters in the costing model. 


\section{Box 6.2 Cost Parameters}

A three-step process was used to approximate model parameters across programs and quality levels. First, studies on the characteristics and costs associated with early childhood programs were reviewed (e.g., Bernal 2013; Faverio, Rivera, and Cortázar 2013). Second, data on the variation of quality parameters across early childhood programs in Latin America and the Caribbean surveyed by Araujo, López Boo, and Puyana (2013), such as children per caregiver ratio, were used to approximate the characteristics of basic- and enhanced-quality programs in the region. Third, early childhood experts were consulted for final decisions. The values assumed for key parameters are presented in Table B6.1.

Table B6.1 Cost Parameters for Early Childhood Programs Analyzed

\begin{tabular}{|c|c|c|c|c|c|c|}
\hline & \multicolumn{2}{|c|}{ Home visits } & \multicolumn{2}{|c|}{ Day care } & \multicolumn{2}{|c|}{ Preschool } \\
\hline & Basic & Enhanced & Basic & Enhanced & Basic & Enhanced \\
\hline \multicolumn{7}{|l|}{ Panel a. Structural quality } \\
\hline \multicolumn{7}{|l|}{ Human resources } \\
\hline Children per caregiver & 40 & 15 & 12 & 12 & 18 & 12 \\
\hline $\begin{array}{l}\text { Caregivers' years of } \\
\text { education }\end{array}$ & 9 & 11 & 9 & 16 & 14 & 16 \\
\hline $\begin{array}{l}\text { Payment relative to } \\
\text { market compensation (\%) }\end{array}$ & 100 & 110 & 50 & 110 & 100 & 110 \\
\hline $\begin{array}{l}\text { Infrastructure } \\
\text { Dedicated classroom } \\
\text { space }\left(\mathrm{m}^{2}\right)\end{array}$ & $\mathrm{N}$ & $\mathrm{N}$ & $\mathrm{N}$ & 2 & 1.5 & 2 \\
\hline \multicolumn{7}{|l|}{ Nutrition } \\
\hline Lunch, afternoon snack & $\mathrm{N}$ & $\mathrm{N}$ & $\mathrm{Y}$ & $\mathrm{Y}$ & $\mathrm{N}$ & $\mathrm{N}$ \\
\hline \multicolumn{7}{|l|}{ Panel b. Process quality } \\
\hline $\begin{array}{l}\text { Training and supervision } \\
\text { Initial training (weeks) }\end{array}$ & 2 & 4 & 2 & 4 & 2 & 4 \\
\hline Caregivers per supervisor & 20 & 10 & 20 & 10 & 20 & 10 \\
\hline
\end{tabular}

Notes: $\mathrm{N}=$ no; $\mathrm{Y}=$ yes. Payment relative to market compensation corresponds to the ratio between wages paid to providers and the average market wage for individuals with the same educational attainment.

Source: Author's elaboration. 
The basic-quality home visits program involved a monthly home visit complemented with two group visits at community centers. The enhanced-quality option involved weekly home visits. Basic-quality daycare involved a home-based model, while a center-based model was assumed for the enhanced-quality option. Finally, both the basicand enhanced-quality options for preschool involved the provision of educational services in centers.

\section{Letting Numbers Speak for Themselves}

Table 6.4 presents costs per child of four programs-each with four combinations of basic and enhanced structural and process qualityfor Chile, Colombia, and Guatemala. Comparisons of the different options suggest several important points about program costs that can better inform choices among early childhood policy options.

Take, for example, the case of preschools. Higher structural quality preschools have fewer children per teacher and more classroom space per child; teachers have more schooling and higher compensation,

Table 6.4 Estimated Annual Program Costs per Child in Alternative Programs (\$ pear Child)

\begin{tabular}{lcccc}
\hline $\begin{array}{l}\text { Process quality } \\
\text { Structural quality }\end{array}$ & $\begin{array}{c}\text { Basic } \\
\text { Basic }\end{array}$ & $\begin{array}{c}\text { Enhanced } \\
\text { Basic }\end{array}$ & $\begin{array}{c}\text { Basic } \\
\text { Enhanced }\end{array}$ & $\begin{array}{r}\text { Enhanced } \\
\text { Enhanced }\end{array}$ \\
\hline a. Chile & & & & \\
Home visits & 242 & 276 & 738 & 871 \\
Daycare & 681 & 758 & 2610 & 2717 \\
Preschool & 977 & 1028 & 1723 & 1815 \\
b. Colombia & & & & \\
Home visits & 187 & 213 & 595 & 714 \\
Daycare & 575 & 642 & 2260 & 2354 \\
Preschool & 817 & 861 & 1492 & 1572 \\
c. Guatemala & & & & \\
Home visits & 116 & 136 & 442 & 515 \\
Daycare & 409 & 450 & 1597 & 1654 \\
Preschool & 630 & 658 & 1055 & 1103 \\
\hline
\end{tabular}

Source: Author's calculations. 
given their years of education. A higher process quality preschool involves more training and more intensive supervision. Differences in costs across quality levels can be analyzed by comparing figures across columns. In Colombia, for example, program costs for the enhanced structural quality option are about 80 percent greater than for the basic structural quality option. In contrast, program costs for the enhanced process quality option are only about 5 percent greater than the basic process quality option.

The results in Table 6.4 are robust across countries and programs: moving from the basic to the enhanced quality option requires substantially larger investments for the inputs related to structural quality (e.g., infrastructure) compared to those related to process quality (e.g., training). The case of daycare is clear: the enhanced structural quality option costs about 300 percent more than the basic structural quality option, whereas enhancing process quality requires only about a 10 percent cost increase. Improving structural quality for home visits requires a cost increase of more than 200 percent, compared with a 15 percent increase for process quality improvement.

Comparisons across programs indicate that home visits are the least expensive option, basically because there are no infrastructure or nutritional costs. For the basic structural quality programs, daycare is less expensive than preschool. Though preschools provide services to children for only 4.5 hours compared to 8 hours in daycare programs, the latter are less expensive because they are homebased (hence, they entail lower infrastructure costs) and providers have lower educational attainment, and thus lower compensation. For the enhanced structural quality option, daycare is more costly compared to preschool because the daycare centers have similar quality parameters in a range of dimensions (such as teachers with 16 years of schooling), but provide care for longer hours.

Finally, comparisons across panels reveal that costs for Chile are about 20 percent higher than for Colombia, whereas costs in Guatemala are about 30 percent lower. These cost differences basically reflect varying wage and price levels, but are less than the differences in per capita income across countries. Thus, the program costs relative to per capita income are highest in Guatemala and lowest in Chile. 


\section{Which Early Childhood Programs Should Be Expanded?}

Early childhood programs differ in costs and government resources are limited. Therefore, governments should implement those programs that allow them to reap greater benefits given costs. This reasoning lends itself to the use of cost-benefit analysis. Akin to investment decisions made in the private sector, governments should invest in those programs with the highest returns.

To apply this methodology the benefits and costs of programs must be monetized. This is not a trivial task as it requires assigning a price for every resource used and monetizing all present and future costs and benefits. The advantage of making some of these (sometimes heroic) assumptions is that this methodology produces a clear ranking of projects. The shortcoming is that the ranking is sensitive to omitting costs or benefits, or valuing them incorrectly.

Of course, efficiency is not the only metric by which governments may want to allocate resources to programs. In fact, redistribution is a key policy concern for government policy, and the crowding-out effect of private expenditure as a consequence of public policy is a key concern in this area. This section provides an illustrative analysis of the potential benefit-cost ratios for home visits, daycare, and preschool programs for children in Chile, Colombia, and Guatemala.

\section{Benefits}

There are two main potential benefits of early childhood programs. First, they can enhance the development of children and generate increases in lifetime productivity. These programs enhance productivity primarily by developing child cognitive and other skills-which in turn augment academic achievement and schooling attainment in later childhood and adolescence-which leads to increases in productivity and income in adulthood (Table 6.5). Second, certain programs provide custodial care for parents. In other words, parents can leave their children someplace where they will be safe and healthy for a certain number of hours while parents spend their time in other activities. This service benefits families by reducing expenses and saving time. These services are especially 
Table 6.5 Impact of Better Early Childhood Development through Subsequent Lifecycle Stages

\begin{tabular}{ll}
\hline Stage & Key outcomes \\
\hline \multirow{2}{*}{ Preschool } & Cognitive skills \\
& Socioemotional skills \\
& Cognitive skills \\
Childhood & Socioemotional skills \\
& Academic achievement \\
& Schooling attainment \\
& Cognitive skills \\
Adolescence & Socioemotional skills \\
& Academic achievement \\
& Schooling attainment \\
Adulthood & Income \\
& Productivity \\
\hline
\end{tabular}

Source: Author's elaboration.

relevant for daycare programs that typically provide full-time care and, hence, facilitate mothers' participation in the labor market. To a lesser extent, they are also relevant for preschools that typically provide only part-time care.

Access to early childhood programs can have other long-term benefits for children as they influence their decisions as an adult to engage in crime, civic duty, and family formation. These benefits to society are difficult to quantify but are nonetheless important. For example, the cost-benefit analysis of a high-quality preschool intervention in the United States computed a present discounted benefit for society in terms of reduced criminal activities of about $\$ 6$ for each dollar spent in the program (Belfield and others 2006). Given the lack of data necessary to monetize these benefits in the case of Latin America and the Caribbean countries, we do not include them in the quantitative analysis. Hence, the benefit-cost ratios of the analyzed programs may be even larger than the ratios presented here.

Notice that adult productivity gains due to early childhood programs are likely to occur in both market and nonmarket activities. The empirical challenges in estimating the monetary value of gains in nonmarket productivities are substantial and virtually 
unsurmountable. Therefore, the estimates in this chapter assume that changes in adult productivity due to early childhood programs are the same in market and nonmarket activities. Ideally, estimates of the productivity impacts of early childhood programs would be made by following children in Latin America and the Caribbean with different exposures to programs when they are $0-5$ years of age through their adult lives, decades later. Data do not exist to estimate the direct impact of such programs on adult productivity for most Latin American and Caribbean early childhood programs. Instead, the estimates in this chapter are based on the links in the sequence of lifecycle stages in Table 6.5, and the assumption that adult labor market earnings reflect adult productivity.

The first link pertains to the impact of early childhood programs on cognitive skills. Tables 6.6 and 6.7 summarize the limited systematic evidence on this link from Latin America and the Caribbean for home visits (Table 6.6) and daycare and preschool (Table 6.7). ${ }^{4}$ Effects on child cognitive skills are expressed in standard deviations. ${ }^{5}$

Evaluations of home visits account for the majority of the studies in Tables 6.6 and 6.7. Most of these home visit evaluations, however, are for small-scale experiments carried out in Jamaica, which makes it difficult to generalize these results to large-scale programs and other contexts. The average impact of home visits on children's cognitive skills is 0.63 of a standard deviation in cognitive skills, with a range from 0.19 to 1.26 . These are large impacts and indicate considerable promise for such programs. However, these estimates raise at least two questions. First, why is the variation so great for Jamaica? Probably, program quality varies substantially even within similar contexts in a country with a relatively small population. Second, would these estimates largely from small experiments and primarily from one country hold up if the programs were scaled up in other countries? The answer would appear to be yes, based on three estimates for studies beyond Jamaica, including two on a larger scale. All three estimates are relatively close to the average $(0.19$ for Colombia, 0.55 for Ecuador, and 0.72 for Brazil).

As discussed in Chapters 4 and 5, evidence on the impact of daycare and preschool programs in Latin America and the Caribbean is very limited. The estimates for Bolivian and Colombian daycare 
Table 6.6 Impact of Home Visits on Cognitive Skills

\begin{tabular}{|c|c|c|c|c|c|c|}
\hline Evaluation & $\begin{array}{l}\text { Total } \\
\text { visits }\end{array}$ & $\begin{array}{l}\text { Duration } \\
\text { (months) }\end{array}$ & $\begin{array}{l}\text { Visits per } \\
\text { month }\end{array}$ & Country & $N$ & $\begin{array}{c}\text { Cognitive } \\
\text { skills effects } \\
\text { (SD) }\end{array}$ \\
\hline $\begin{array}{l}\text { Grantham-McGregor, } \\
\text { Schofield, and } \\
\text { Harris (1983) }\end{array}$ & 129 & 36 & 3.6 & Jamaica & 39 & 1.26 \\
\hline $\begin{array}{l}\text { Powell and Grantham- } \\
\text { McGregor (1989)- } \\
\text { Visits weekly }\end{array}$ & 103 & 24 & 4.3 & Jamaica & 58 & 1.15 \\
\hline $\begin{array}{l}\text { Grantham-McGregor } \\
\text { and others (1991) }\end{array}$ & 103 & 24 & 4.3 & Jamaica & 123 & 0.86 \\
\hline $\begin{array}{l}\text { Rosero and Oosterbeek } \\
\text { (2011) }\end{array}$ & 90 & 21 & 4.3 & Ecuador & 1,473 & 0.55 \\
\hline $\begin{array}{l}\text { Attanasio and others } \\
\text { (2014) }\end{array}$ & 77 & 18 & 4.3 & Colombia & 1,263 & 0.19 \\
\hline $\begin{array}{l}\text { Powell and Grantham- } \\
\text { McGregor (1989) - } \\
\text { Visits biweekly }\end{array}$ & 52 & 24 & 2.2 & Jamaica & 94 & 0.34 \\
\hline $\begin{array}{l}\text { Powell and Grantham- } \\
\text { McGregor (1989)- } \\
\text { Visits monthly }\end{array}$ & 24 & 24 & 1.0 & Jamaica & 90 & 0.20 \\
\hline $\begin{array}{l}\text { Eickmann and } \\
\text { others (2003) }\end{array}$ & 10 & 5 & 2.0 & Brazil & 156 & 0.72 \\
\hline $\begin{array}{l}\text { Gardner and others } \\
(2003)\end{array}$ & 9 & 2 & 4.3 & Jamaica & 140 & 0.38 \\
\hline Average & 66 & 20 & 3.4 & - & 382 & 0.63 \\
\hline
\end{tabular}

Notes: $N=$ number of observations. Cognitive skills effects are presented in standard deviations (SD). Source: Author's elaboration.

programs indicate a positive impact of about 0.20 standard deviation in cognitive skills scores, but the estimates for Ecuador are about the same magnitude and opposite in sign. The estimate for Ecuador does not seem to be the result of any design flaws in the study or other potential problems with the methodology. Overall, on average, these three Latin American and Caribbean daycare programs have an impact of 0.06 standard deviations on cognitive skills. For preschool, only one study has presented solid evidence on the impact on children's cognitive skills. In this case, attending preschool in 
Table 6.7 Impact of Daycare and Preschool on Cognitive Skills and Academic Achievement

\begin{tabular}{|c|c|c|c|c|}
\hline Evaluation & $\begin{array}{c}\text { Children per } \\
\text { provider }\end{array}$ & Country & $N$ & $\begin{array}{l}\text { Effect size } \\
\text { (SD) }\end{array}$ \\
\hline \multicolumn{5}{|c|}{ a. Effects of full-time daycare on child cognitive skills } \\
\hline Behrman, Cheng, and Todd (2004) & 5 & Bolivia & 1,489 & 0.19 \\
\hline Bernal and others (2009) & 12 & Colombia & 1,263 & 0.20 \\
\hline Rosero and Oosterbeek (2011) & 9 & Ecuador & 769 & -0.21 \\
\hline Average & 9 & n.a. & 1,174 & 0.06 \\
\hline \multicolumn{5}{|c|}{ b. Effects of part-time preschool on academic achievement } \\
\hline Berlinski, Galiani, and Gertler (2009) & n.d. & Argentina & 121,811 & 0.24 \\
\hline Average & n.d. & n.a. & 121,811 & 0.24 \\
\hline
\end{tabular}

Notes: n.d. = no data; n.a. $=$ not applicable; $\mathrm{N}=$ number of observations. Effects are presented in standard deviations (SD) and were measured at the end of exposure for daycare programs (ages 3-5) and in third grade for preschool (age 8).

Source: Author's elaboration.

Argentina had a positive impact of 0.24 standard deviations on third grade academic achievement.

Home visits and daycare programs vary dramatically in their effects on child cognitive skills. ${ }^{6}$ Figure 6.4 ranks the evaluations in this regard. The figure highlights the stark differences in impact between the two types of programs. While the home visit interventions produced effects between 0.2 and 1.2 standard deviations, the effects for daycare programs range between -0.2 and 0.2. The home visit programs produced average effects on cognitive skills about 10 times larger than daycare programs ( 0.63 versus 0.06$)$.

In considering these values, it is important to keep two things in mind. First, these numbers only reflect the benefits of the programs that were evaluated, and not the universe of programs. For example, daycare of higher quality would likely result in greater impacts on child development and parenting programs of lower quality would result in lesser impacts.

Second, the evaluations of daycare and preschool programs measure the effects on child development when children attend these programs instead of receiving the care arranged by their parents in the absence of government intervention. The care in the absence of 
Figure 6.4 Effects on Cognitive Skills of Home Visits versus Daycare Programs

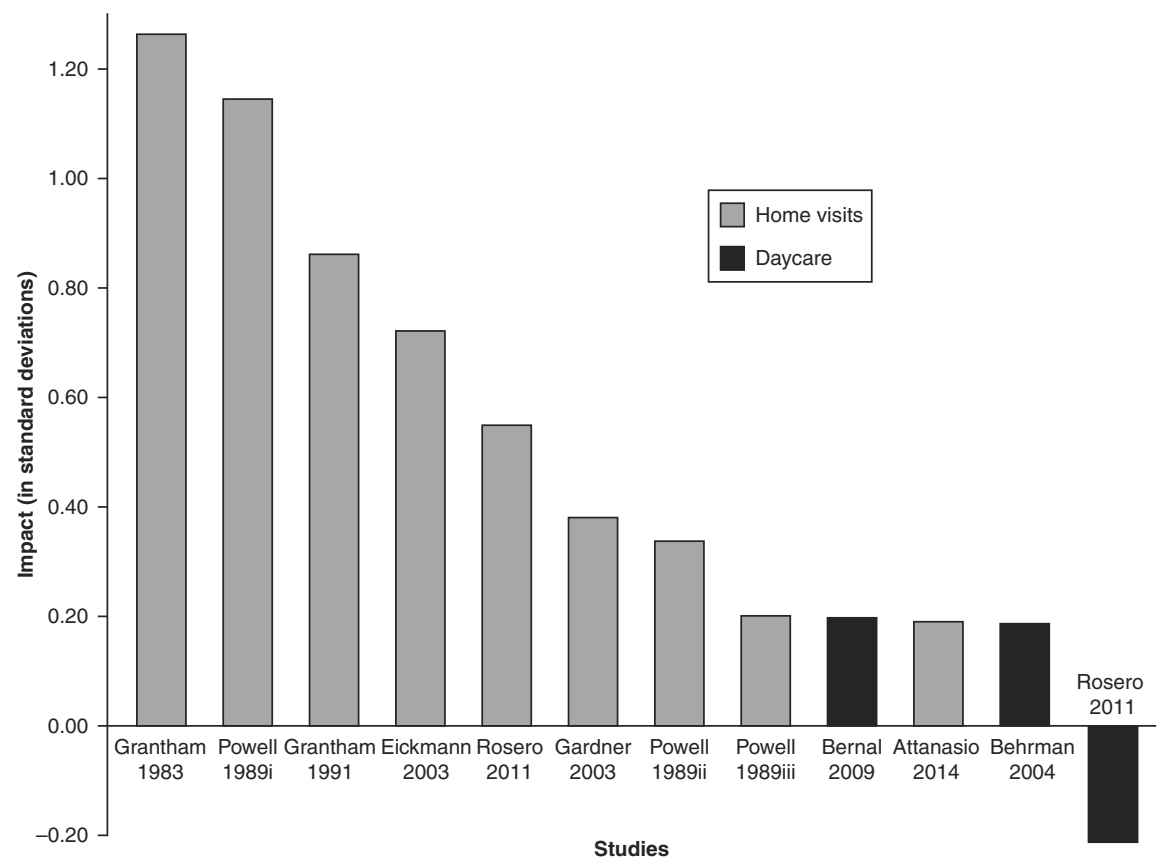

Notes: Powell i refers to the weekly program. Powell ii refers to the biweekly program. Powell iii refers to the monthly program.

Source: Author's calculations.

government intervention could include a nonpaid caregiver such as the mother, the grandmother, or any other relative. Alternatively, such care could include a paid caregiver such as a babysitter or a private daycare. That is, these evaluations do not measure the effect of attending daycare per se against a specific alternative such as mother care. Instead, the evaluations document how child development would be affected by attending publicly funded daycare instead of the childcare arrangement that otherwise would be used.

The next step in estimating adult productivity benefits is to link the impact of various Latin American and Caribbean early childhood programs on childhood cognitive skills to outcomes such as schooling achievement and attainment, and adult earnings, assumed to be related to productivity (see Table 6.8). There are few 
Table 6.8 Impact of Three Early Childhood Experimental Evaluations That Followed Children into Early Adulthood

\begin{tabular}{lcccc}
\hline & $\begin{array}{c}\text { Perry } \\
\text { Preschool } \\
\text { Project }\end{array}$ & $\begin{array}{c}\text { Carolina } \\
\text { Abecedarian }\end{array}$ & $\begin{array}{c}\text { Jamaica } \\
\text { stimulation } \\
\text { study }\end{array}$ & Average \\
\hline Cognitive skills & 0.89 & 0.93 & 0.86 & 0.89 \\
Achievement & 0.33 & n.d. & n.d. & 0.33 \\
Grades of schooling attainment & 0.90 & 1.15 & 0.61 & 0.89 \\
Earnings (\% change) & 0.28 & 0.61 & n.d. & 0.45 \\
Employment (\% change) & 0.20 & 0.42 & 0.18 & 0.27 \\
Earnings for those employed & 0.06 & 0.14 & 0.30 & 0.17 \\
(\% change) & & & & \\
\hline
\end{tabular}

Note: n.d. = no data.

Source: Author's elaboration.

studies that permit direct estimates of such linkages, and only one for Latin America and the Caribbean. Table 6.8 summarizes some longer-term linkages at least into young adulthood drawing from a Jamaican study on home visits and two studies from the United States. The Jamaican program provided psychosocial stimulation to growth-stunted children living in poverty. The two studies from the United States were the Perry Preschool Study and the Carolina Abecedarian program. In the former, low-socioeconomic-status children attended a preschool and their families received a weekly home visit. The Carolina Abecedarian program was a more intensive program, providing eight-hour care for children from birth to age 5 , a stimulating curriculum, and nutritional and health services. All these programs positively impacted a number of important dimensions of child development; in some cases, these persisted over a number of years as the children aged.

Beyond the potential effects of early childhood programs on children's human capital development, daycare (and to a lesser extent preschool programs) also provides custodial care to families. Ideally, these benefits would be monetized using information on how much families value this service, that is, how much families are willing to pay for custodial care. However, plausible estimates of families' willingness to pay for this service are typically unavailable for the countries considered. Still, it is important to factor this service into the 
cost-benefit calculation to ensure a fair comparison across early childhood programs. Based on conceptual considerations, it was assumed that families' valuation of the custodial care benefit was 75 percent of the cost of the service provided for preschool and daycare. ${ }^{7}$ The ranking of the three analyzed programs in terms of their benefit-cost ratios is robust to choosing alternative plausible valuations.

Of course, the benefits to society of providing childcare might not be circumscribed to the individual willingness to pay for the service. For example, daycare programs that facilitate an increase in female labor supply could have a strong public policy rationale for several reasons. First, they can be seen as an instrument to promote female labor force participation (which is low in many Latin American and Caribbean countries; see Box 6.3) and gender equality. Second, womens' decisions to enter the labor force could be distorted if their wages do not reflect their market productivity. In fact, the evidence suggests that this may be the case as wage gaps across genders in the region remain unexplained even after controlling for numerous characteristics (Atal, Nopo, and Winder 2009). Third, increases in female labor supply could generate other difficult-to-quantify benefits, including reductions in family violence, spending changes due to differences in consumption preferences across genders, and an overall boost in women's self-esteem and social standing in society.

\section{Box 6.3 Women in the Labor Market}

The decision to participate in the labor market is affected by family characteristics. Particularly among women, the presence of children and related childcare activities are a major determinant of labor supply. The issue has long been well understood by scholars and policymakers who have argued that childcare-related policies could be a useful tool to increase the participation of women in the labor market. While the focus of this book is on child well-being, it is useful to see if some of the policies considered have at least the potential to impact female labor supply in the labor market. Data from 18 household surveys in Latin America and the Caribbean provide the basis for some descriptive evidence. The focus is on 25- to 55-year-old women with at least one child 0-5 years of age. 
Figure B6.1 Labor Force Participation: Latin America and All Available Countries (1992-2012)

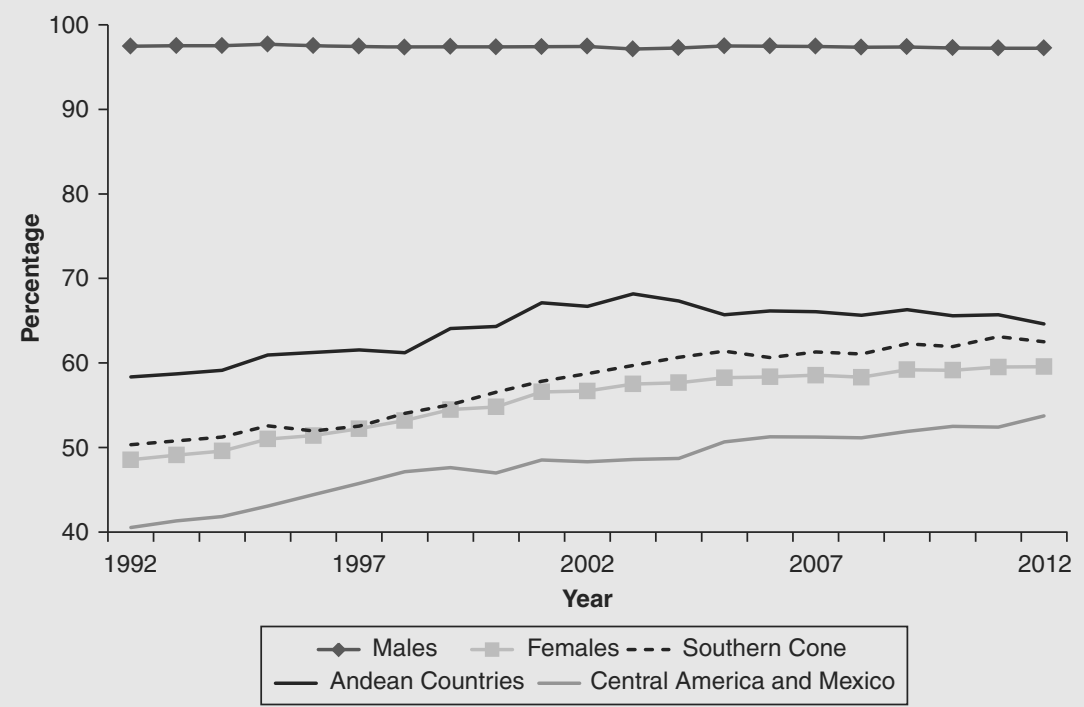

Source: Household and labor surveys collected by national statistical offices.

Figure B6.1 presents the participation rate of men and women over time. $^{8}$ Three main results are immediately evident:

1. While the male participation rate has been very stable, female participation of prime age women with young children has been increasing over time.

2. This increase over time of female participation has been leveling off since the early 2000s.

3. The current gender differential in participation is significant in all countries in the region, ranging between 30 and 50 percentage points.

Figure B6.2 presents the participation rate of women with young children according to three education categories. Two main results emerge:

1. Participation rates are increasing for women in all schooling levels for all countries in the region.

2. In all countries where there is a clear time trend, the trend is common to all three education categories. 
Figure B6.2 Female Labor Force Participation by Education Category, Average for Latin America (1992-2012)

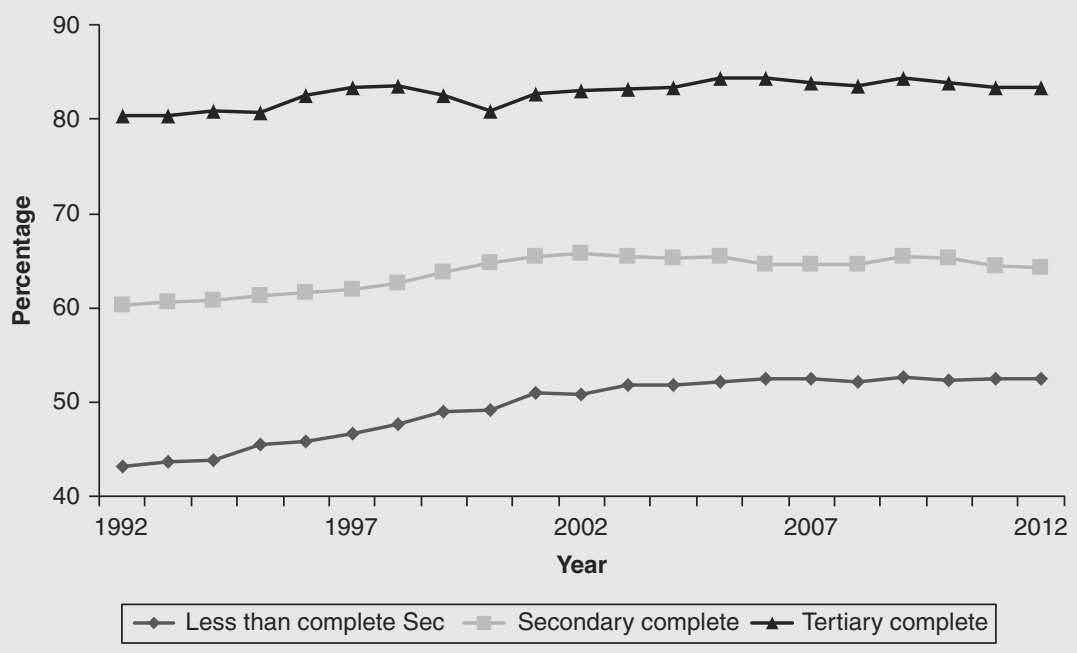

Note: Sample $=$ prime-age individuals with children $0-5$ years old.

Source: Household and labor surveys collected by national statistical offices.

In sum, there is substantial room to increase female labor participation since women's participation is between 30 and 50 percentage points lower than men's. This is particularly true for women with lower levels of education.

\section{Costs}

The resource costs of an early childhood program are not equivalent to the program costs that directly affect governmental budgets for several reasons. To start with, if these programs cause children to attend additional grades of schooling, as suggested in Table 6.8, then there are public outlays for this schooling. Moreover, if children stay longer in schools, we could expect reduced earnings due to a delay in their entrance to the labor market. Finally, if governments must raise revenue to finance early childhood programs, then raising revenue causes distortions that entail real costs. The resource cost estimates incorporate all these elements. 


\section{Benefit-Cost Ratios}

The benefit-cost ratios are simply the ratio of the benefits to the resource costs, all in present discounted terms. If the benefits exceed the costs, this ratio exceeds 1 and the program therefore merits serious consideration. Table 6.9 presents benefit-cost ratios for home visits, daycare, and preschool for Chile, Colombia, and Guatemala. These estimates use a 3 percent discount rate, as is common for many social sector programs.

The patterns in these estimated benefit-cost ratios are similar across the three different countries. This suggests they may also hold for other countries in Latin America and the Caribbean. The highest benefit-cost ratios are for preschool, with benefits about four times the resource costs. The second highest benefit-cost ratios are for home visits, with benefits about three times the resource costs. These two types of early childhood programs look promising, with benefits expected to significantly exceed costs. In contrast, the benefit-cost ratios for daycare are much lower, around 1. For the latter, however, benefits do not account for any market imperfections that could generate low demand or supply of daycare services that public subsidies could help tackle.

These estimated benefit-cost ratios for home visits and daycare are based on the average effects of the multiple studies in Tables 6.5 and 6.6 (but there is only one study in Table 6.6 for preschool). The estimates may be sensitive to the impact of one particular and possibly idiosyncratic study. For home visits, this is not the case. The benefit-cost ratios change slightly if any of the underlying studies are dropped. For daycare, however, the benefit-cost ratios are sensitive to which studies are included. They increase to over 2 if the

Table 6.9 Benefit-Cost Ratios for Home Visits, Daycare, and Preschool with a Discount Rate of 3\%

\begin{tabular}{lccc}
\hline & Home visits & Daycare & Preschool \\
\hline Chile & 3.5 & 1.5 & 4.3 \\
Colombia & 2.6 & 1.1 & 3.4 \\
Guatemala & 3.6 & 1.2 & 5.1 \\
\hline
\end{tabular}

Source: Author's calculations. 
Ecuadorian study is dropped. But they drop to 0.5 if the Ecuadorian study is included and one of the other studies is dropped. The implication is that the estimated benefit-cost ratios may be sensitive to the context considered.

Three important caveats should be noted. First, most of the evaluations that were used to estimate the effect of programs on child cognitive skills or academic achievement refer to interventions that targeted poor populations. Similarly, the three long-term studies that were used to predict the effect of increases in early childhood development on productivity and wages focused on low-socioeconomic populations. Hence, this analysis provides strong support for expanding services focused on poor populations. It is not clear, however, whether the predicted benefits would materialize if programs do not actively target services to such populations.

Second, the benefit-cost ratios in Table 6.9 are informative of expected effects of programs similar to those reviewed here. For example, the typical home visit programs provided weekly home visits to participant families and had a strong training and supervision component. Consequently, home visit programs that share these features can be considered highly promising. But less intense programs (in terms of frequency of visits or overall quality) may not generate the documented high benefit-cost ratios.

Third, the number of available evaluations is small, and many do not refer to at-scale programs. It is, therefore, important to be cautious in generalizing from these results. Ideally, a government would gradually build up the knowledge base on the impacts of parenting, daycare, and preschool programs, and use these estimates to revise the cost-benefit calculations mentioned earlier, and make decisions about the allocation of resources.

\section{Public Intervention without Stepping on Private Toes}

Beyond the rationale for governmental intervention in early childhood development, it is also important to consider whether public expansion of a service can displace (crowd out) private supply. In an extreme case of complete crowding out, the opening of a public preschool of a certain size induces the closure of a private facility 
with similar enrollment and hence the number of children receiving the services remains constant. In this case-assuming that resource costs and qualities are constant across the private and public preschools-no increases in future productivity are expected because the type of services received by children does not change. Thus, the governmental intervention simply transfers resources from taxpayers to families with children enrolled in the public facility.

To produce actual increases in service coverage, it is necessary to limit the extent to which expanding public services crowd out private service providers. The evidence from studies of preschool expansions in Argentina and Brazil suggests little crowding out in these contexts (Berlinski, Galiani, and Gertler 2009; Bastos and Straume 2013). On the other hand, crowding out can be substantial with other services, in particular daycare (Paes de Barros and others [2011] present evidence for Brazil). Policymakers can employ different strategies to reduce crowding-out effects. To start with, the government can target expansions geographically to areas with low penetration of private providers. For example, typically highquality private suppliers have a limited presence in less populated areas; hence the risk of displacing private supply with public supply is lower. More generally, crowding out will be lower in areas with fewer private suppliers compared to areas where they are more common.

Moreover, just because the use of governmental resources to support early childhood investments may be warranted does not mean that governments should necessarily operate early childhood services. Instead, governments can provide subsidies directly to suppliers or indirectly to consumers regardless of the ownership-public or private-of the service provider. In fact, the evaluation by Rosero and Oosterbeek (2011) described earlier analyzes the effects on child development of attending daycares run by NGOs and funded by the government in Ecuador. Similarly, the government of Mexico runs a large-scale program that provides funding to private daycares attended by young children (Estancias Infantiles) to support working mothers.

Furthermore, the government can introduce eligibility requirements to give priority to consumers with low underlying demand 
for private services. This mainly would entail implementing means-tested requirements for program beneficiaries. Finally, the government can actively promote the expansion of early childhood services to low-income households (with low expected demand for private services). This would involve spending resources on community outreach activities and requiring existing conditional cash transfer programs to target enrollment in services in low-income groups.

How important are crowding-out aspects for the three major early childhood programs analyzed? They are particularly relevant for the provision of daycare services. Families in which both parents work full time, have high earnings, and do not have support from family members will demand daycare services even in the absence of public provision. Hence, the free public provision of the service will induce them to switch from private to public providers (especially if the public services offered are similar in quality to those provided by private suppliers). In the case of preschool, most enrollment is currently public or private but publicly subsidized (like in Chile), and providing high-quality free public services may produce small crowding-out effects. Finally, since private and public use of home visits is low, crowding-out effects are expected to be minimal when expanding home visit programs.

\section{The Price Tag}

Armed with an analysis to guide policy decisions on expanding early childhood services and assuring service quality, the question becomes, how much will potential expansions cost? This issue is particularly important given expected constraints in public budgets for Latin American and Caribbean countries in the coming years (Powell 2014). The answer depends on a country's population in the target age ranges, rural/urban composition (because of higher expected costs in rural areas), type of programs and their quality, and the program costs per child. To illustrate, consider two possible scenarios (Table 6.10).

Expansion option A: Expand coverage of home visits (1- to 2-yearolds) and preschool programs (3- to 5-year-olds) with enhanced 
Table 6.10 Expansion Options: Simulated Additional Program Costs (Percentage of GDP)

\begin{tabular}{|c|c|c|c|c|c|c|}
\hline \multirow[b]{2}{*}{ Program types } & \multicolumn{2}{|c|}{ Chile } & \multicolumn{2}{|c|}{ Colombia } & \multicolumn{2}{|c|}{ Guatemala } \\
\hline & $\mathbf{A}$ & B & A & B & A & B \\
\hline Home visits & 0.01 & 0.02 & 0.01 & 0.03 & 0.02 & 0.08 \\
\hline Daycare & 0.00 & 0.15 & 0.00 & 0.31 & 0.00 & 0.79 \\
\hline Preschool & 0.03 & 0.05 & 0.06 & 0.11 & 0.16 & 0.27 \\
\hline Total & 0.03 & 0.21 & 0.07 & 0.45 & 0.18 & 1.14 \\
\hline
\end{tabular}

Source: Author's calculations.

process quality and basic structural quality by 10 percentage points. This scenario requires additional program costs as a share of GDP ranging from 0.03 percent in Chile to 0.07 percent in Colombia to 0.18 percent in Guatemala.

Expansion option B: Expand coverage for home visits, daycare, and preschool with enhanced structural and process quality by 10 percentage points. This scenario requires a fiscal effort that is about six-seven times higher than option $\mathrm{A}$.

These simulations illustrate some important points. First, because of differences in program costs, the composition of programs matters a lot. Implementing programs of enhanced structural quality increases costs substantially. The additional governmental budgetary commitments are much more feasible when focused on home visits and preschool and low investment in structural quality. Expanding home visits and preschool programs significantly while ensuring adequate investments in process quality will not demand large fiscal outlays.

Second, even though the costs per program beneficiary are lower for countries like Guatemala, the program costs for a given expansion are higher as a proportion of GDP because the percentage of the population in the targeted age ranges and in rural areas is higher, and program costs per beneficiary relative to per capita income are also higher. Moreover, if poverty is taken as a measure for targeting, implementing these programs in the poorest countries is far more onerous. Taking a poverty rate of $\$ 2.5$ a day, 3 percent of children in Chile are poor while 58 percent of those in Guatemala are poor. Therefore, expanding home-visits of enhanced-structural quality 
for the poor in Chile will cost 0.0015 percent of GDP in Chile but 0.12 percent of GDP in Guatemala. Hence, different countries should be expected to choose distinct quality and coverage options based on their economic and budgetary restrictions.

\section{The Bottom Line}

Latin American and Caribbean countries face two major policy challenges. First, average per capita productivity has inched up slowly in the past five decades (Powell 2014). Second, inequality levels in the region, though recently falling, are still among the highest in the world (World Bank 2013). Hence, policy options that can tackle both challenges should receive considerable public attention. Investing in early childhood development is one of these options. Early childhood programs tend to produce high returns given their costs, and can be targeted at underserved populations to boost not only productivity but also equity. However, simply increasing investments is not enough. The expected returns of greater investments will depend largely on the characteristics of the programs expanded. Hence, policymakers should carefully weigh early childhood policy options to maximize the returns on the expected investments.

This chapter reviews critically the existing evidence on benefits and costs of options to provide some quantitative guidance for policy decisions. In terms of program expansion, the analysis suggests that preschool and home visits generate larger returns per dollar spent than daycare. The sizeable expansion of preschool services that countries have undertaken in recent decades can be expected to help build human capital in the future. Thus, the current allocation of about half of the early childhood public budget to preschool education seems warranted, given the limited available evidence. On the other hand, an opportunity lies ahead. Public spending in home visits is low in the region, leaving much room to expand these programs in the coming years. However, pilot projects should precede major expansions.

Governments that seek to improve child development and facilitate the incorporation of women into the labor market may face a difficult trade-off. On the one hand, in the region, parenting and 
preschools have had the greatest impact on child development; however, these programs are unlikely to impact female labor supply significantly. On the other hand, daycare programs can make it easier for women to work; however, unless they are of high quality, daycare programs will not benefit children. To minimize this trade-off, it is critical that governments in the region look for realistic options to increase the quality of daycare at a reasonable cost. One option is to combine daycare with a parenting intervention delivered at the daycare center, as is typical of high-quality daycare programs for disadvantaged families in developed countries. The combination of both services could create important costs savings. Another option is to invest in improving process quality in daycare centers, as discussed in Chapter 4.

The analysis of this chapter (and the book in general) makes evident that in the region decisions are made with a limited knowledge base circumscribed to few programs and contexts. Assuming that Latin America and the Caribbean increase investments in early childhood by 0.5 percent of GDP, new spending in this area should reach about $\$ 30$ billion per year. The costs of mistakes, therefore, can be very large. These costs can be lessened by devoting a small percentage of this increased spending to carefully design pilot studies and to monitoring and evaluating new programs. Generating solid evidence on actual impacts can go a long way to ensuring that investments in early childhood development contribute to sustained improvements in standards of living and lower inequality and poverty in the region.

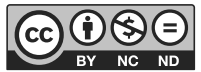

Except where otherwise noted, this work is licensed under a Creative Commons Attribution-NonCommercial-NoDerivatives 3.0 IGO License. To view a copy of this license, visit https://creativecommons. org/licenses/by-nc-nd/3.0/igo/ 